\title{
Zaštitni i rizični faktori u razvoju karijere te moguće intervencije u školskom kontekstu
}

\author{
Iva Šverko i Toni Babarović \\ Institut društvenih znanosti Ivo Pilar, Zagreb, Hrvatska
}

\begin{abstract}
Sažetak
U ovom radu opisuju se i sistematiziraju zaštitni i rizični faktori koji mogu djelovati na profesionalni razvoj pojedinca. Ponuđena je konceptualizacija zaštitnih i rizičnih faktora unutar tri domene osobne, relacijske i situacijske. Osobni su faktori psihološke osobine za koje je u literaturi potvrđeno da imaju utjecaja na profesionalni razvoj, poput ekstraverzije, savjesnosti, orijentacije prema budućnosti, optimizma, fleksibilnosti, otpornosti na stres, samoefikasnosti, kognitivnih kapaciteta ili pak zdravlja pojedinca. Relacijski faktori obuhvaćaju socijalne utjecaje koji mogu djelovati pozitivno ili negativno na profesionalni razvoj, počevši od utjecaja roditelja, vršnjaka te društva u cjelini, primjerice kroz socijalnu podršku za razvoj karijere, ali i roditeljske i odgojne stilove. Situacijski faktori predstavljaju različite vanjske utjecaje koji mogu djelovati na razvoj karijere, od kojih su u literaturi jasno prepoznati socioekonomski status te prilike u mjestu stanovanja pojedinca. U radu se razmatraju utjecaji zaštitnih i rizičnih faktora na razvoj karijere i prikazuju se dosadašnja istraživanja u tom području. Također, u radu se upućuje na dostupne alate za profesionalno usmjeravanje adolescenata koji mogu ublažiti neželjeno djelovanje rizičnih faktora.
\end{abstract}

Ključne riječi: razvoj karijere, zaštitni i rizični faktori, profesionalno usmjeravanje, adolescencija

\section{Uvod}

Teorije izbora i razvoja karijere podrazumijevaju da čovjek treba težiti ostvarenju svojih vrijednosti i potencijala te da odluke o svojoj karijeri treba donijeti nakon zrelog poznavanja sebe i raznih profesionalnih opcija. Međutim, dok neki adolescenti motivirano razmatraju različite profesionalne opcije i donose odluke $\mathrm{u}$ skladu sa svojim interesima, na profesionalne izbore dijela adolescenata djeluje niz faktora koji ograničavaju mogućnosti njihova odabira. To, na primjer, može biti

Iva Šverko, Institut društvenih znanosti Ivo Pilar, Marulićev trg 19, 10000 Zagreb, Hrvatska. E-pošta: iva.sverko@pilar.hr

Ovaj rad je financiran sredstvima Instituta društvenih znanosti Ivo Pilar u okviru Višegodišnjeg financiranja za 2018. (projekt „Identifikacija zaštitnih i rizičnih faktora u karijeri kroz životne faze“"). 
školski uspjeh zbog kojeg ne mogu upisati školu koju žele, socioekonomski status obitelji zbog kojeg nemaju prilika za željeno obrazovanje, sklonost da se povinuju željama svojih roditelja, planovima svojih vršnjaka ili pak rodnim stereotipima. To mogu biti i osobine ličnosti ili niska samoefikasnost koje im onemogućavaju da se nose sa stresom odluke i da samostalno odlučuju. Prema našim očekivanjima pojedinci koji mogu birati svoje zanimanje bit će intrinzično motivirani za izbor i razvoj svoje karijere, željet će ostvariti svoje profesionalne preferencije i postići će bolje ishode u karijeri. S druge strane, pojedinci koji nemaju slobodu da autonomno donesu profesionalne odluke neće biti motivirani za izbor i razvoj svoje karijere, teže će ostvariti svoje profesionalne preferencije, a posljedično će i njihovi profesionalni ishodi biti lošiji.

Klasični teorijski pristupi, poput Hollandova (1959) i Superova (1953), ne uzimaju u velikoj mjeri u obzir ni ograničenja izbora, ni motivacijske faktore $\mathrm{u}$ podlozi profesionalne odluke. Noviji pristupi dotiču različite facilitirajuće i inhibirajuće faktore koji djeluju na proces izbora pojedinca, pa tako ističu važnost socijalne podrške i barijera (Lent, Brown i Hackett, 1994), rodnih stereotipa (Gottfredson, 1981) ili niza adaptivnih psiholoških osobina koje mogu djelovati na profesionalni razvoj i profesionalne ishode (Savickas, 1997). Međutim, niti jedna se od tih teorija ne bavi širokim spektrom zaštitnih i rizičnih faktora u izgradnji karijere, koji neosporno djeluju na mogućnosti profesionalnog odabira. Stoga smatramo da bi uključivanje rizičnih faktora kao važnih odrednica razvoja karijere moglo pomoći rasvjetljavanju važnih, još neodgovorenih istraživačkih pitanja u ovom području, kao i razvoju pravednijega, inkluzivnijeg društva.

U ovom radu želimo prezentirati zaštitne i rizične faktore koji djeluju na profesionalni razvoj adolescenata, opisati učinke praksi profesionalnog usmjeravanja te predstaviti besplatne alate za profesionalno usmjeravanje dostupne u Hrvatskoj, koji mogu ublažiti djelovanje rizičnih faktora.

\section{Kongruencija i profesionalna zrelost}

Od početaka psihologije izbora zanimanja i razvoja karijere, s pojavom prvih teorija, prepoznala su se dva temeljna smjera - diferencijalistički (Holland, 1959, 1997) i razvojni (Super, 1953, 1994). Diferencijalistički pristup naglašavao je važnost dobrog odabira, koji treba biti temeljen na interesima pojedinca. Pojedinci koji će se zaposliti u zanimanju koje je u skladu s njihovim interesima bit će zadovoljniji i uspješniji u svom poslu, manje će mijenjati poslove i manje će izostajati (Holland, 1959). Diferencijalističke teorije naglašavaju kako je za postizanje optimalnih ishoda u karijeri ključno ostvariti kongruentnu poziciju, onu u kojoj su osobine pojedinca u skladu s karakteristikama zanimanja. Različite su se teorije fokusirale na različite aspekte kongruencije, pa je tako Holland (1997) naglašavao važnost interesa, Dawis i Lofquist (1984) vrijednosti, a Gati (1998; Gati, Garty i Fassa, 1996) važnost aspekata posla. Prema diferencijalističkim teorijama izbora 
zanimanja kongruencija osobina pojedinca i radne okoline ključna je za postizanje zadovoljstva poslom, radne angažiranosti i visoke radne uspješnosti (Holland, 1959, 1997; Dawis i Lofquist, 1984). Intervencije utemeljene na ovom pristupu stoga podrazumijevaju upoznavanje pojedinčevih preferencija i sposobnosti, kako bi se pojedincu sugerirao najbolji profesionalni put, odnosno zanimanje sukladno njegovim ili njezinim osobinama. Takve intervencije mogu provoditi stručnjaci za razvoj karijere, koji na osnovi testova, upitnika i intervjua predlažu klijentu adekvatna zanimanja ili obrazovne programe. Također, u tom su pristupu utemeljeni i samoprimjenjivi alati za profesionalno usmjeravanje, koji pojedincu na temelju rezultata na upitniku predlažu prikladna zanimanja ili obrazovne programe.

Razvojni je pristup drugačiji. Za razliku od diferencijalističkog razvojni se pristup ne bavi izborom zanimanja, već razvojem karijere. Razvoj karijere nije jednokratna odluka, već proces u kojem pojedinac višekratno donosi razne odluke koje u konačnici određuju njegove profesionalne ishode. Prema Superu $(1953,1957)$ profesionalni je razvoj cjeloživotni, te pojedinac u različitim fazama karijere treba ostvariti različite razvojne zadatke. Ključ je za postizanje dobrih ishoda u karijeri profesionalna zrelost, odnosno spremnost pojedinca za aktivno usmjeravanje i razvoj vlastite karijere (Super, 1953, 1994). Pojedinac koji je usmjeren na svoj profesionalni razvoj i izgradnju karijere uspješnije će usmjeravati i graditi svoju karijeru te će ostvariti bolje profesionalne ishode. Zato su intervencije utemeljene u razvojnom pristupu prvenstveno usmjerene poticanju profesionalne zrelosti i pružanju podrške u realizaciji razvojnih zadataka izgradnje karijere. To se ostvaruje kroz kontinuirane programe u kojima polaznici tijekom više susreta razvijaju svoju profesionalnu zrelost i stječu kompetencije za samostalno odlučivanje, planiranje i razvoj karijere. Takvi su programi najčešće namijenjeni adolescentima i mogu se odvijati kao duži ili kraći školski programi ili kao samostalne radionice. U njima učenici kroz različite vježbe upoznaju sebe, istražuju profesionalne opcije, mijenjaju stavove o važnosti razvoja karijere i donose profesionalne odluke.

Tradicionalne teorije stavile su naglasak na važnost kongruencije (Holland) i profesionalne zrelosti (Super) za razvoj karijere, no sustavne su empirijske provjere potvrdile tek njihovu umjerenu važnost za postizanje poželjnih profesionalnih ishoda. Brojna su istraživanja ispitivala odnos spomenutih konstrukata i zadovoljstva poslom, radne učinkovitosti ili radne angažiranosti, a opažene su se korelacije u pravilu kretale od niskih do umjerenih.

Temeljna ideja o važnosti kongruencije tek je djelomično potvrđena empirijskim nalazima. Empirijske su provjere i metaanalize pokazale da je kongruencija nisko do umjereno povezana s profesionalnim ishodima (Spokane, Meir i Catalano, 2000; Tranberg, Slane i Ekeberg, 1993; Tsabari, Tziner i Meir, 2005). Kao moguća objašnjenja tih slabih efekata razmatrala su se metodološka ograničenja, poput nesavršenih indeksa kongruencije ili nesveobuhvatnih mjera osobina pojedinca i radne okoline (Tinsley, 2000; Spokane i sur., 2000; Wilkins i Tracey, 2014). Recentni pristupi nude bolje operacionalizacije kongruencije, poput 
indeksa kongruencije temeljenog na cjelokupnom profilu interesa i radnih okolina (npr. Nye, Prasad, Bradbur i Elizondo, 2018; Wille, Tracey, Feys i De Fryut, 2014) ili sustava za procjenu interesa pojedinca i karakteristika radnih okolina koji obuhvaća i nova, moderna područja djelatnosti (Su, Tay, Liao, Zhang i Rounds, 2019). Drugi je pravac istraživanja usmjeren na istraživanje moderacijskih efekata koji potencijalno zamagljuju odnos kongruencije i ishoda, odnosno na pitanje je li kongruencija možda relevantnija za neke pojedince. Kao ključni moderatori tog odnosa prepoznati su fleksibilnost interesa, homogenost radne okoline te kultura (Wilkins i Tracey, 2014). Također, danas se uz važnost kongruencije ističe i motivacijska uloga interesa koji sami za sebe igraju ulogu u objašnjenju profesionalnih i životnih ishoda (Rounds i Su, 2014; Stoll i sur., 2017; Su i sur., 2019; Van Iddekinge, Roth, Putka i Lanivich, 2011), međutim, to je pravac udaljen od klasičnih istraživanja u području kongruencije.

Isto tako, i profesionalna se zrelost pokazala tek nisko do umjereno povezana s profesionalnim ishodima. S obzirom na to da profesionalna zrelost označava spremnost za donošenje kvalitetnih, dobno primjerenih profesionalnih odluka, pod tim se nazivom vrlo često podrazumijeva niz srodnih konstrukata, poput samoefikasnosti u donošenju profesionalnih odluka (Taylor i Betz, 1983), poteškoća i stilova donošenja profesionalnih odluka (Gati, Gadassi i Mashiah-Cohen, 2012; Gati, Krausz i Osipow, 1996), profesionalne adaptabilnosti (Savickas, 1997, 2002; Savickas i Porfeli, 2012a, 2012b), uključenosti u proces konstrukcije karijere (Savickas, 2002) ili pak statusa profesionalnog identiteta (Porfeli, Lee, Vondracek i Weigold, 2011). Navedeni konstrukti zahvaćaju različite, no srodne aspekte profesionalne zrelosti, koji dijele i do $40 \%$ zajedničke varijance, ovisno o njihovim bivarijatnim odnosima (Babarović i Šverko, 2016). Različiti aspekti profesionalne zrelosti umjereno su povezani s profesionalnim ishodima. Primjerice, utvrđeno je da je profesionalna adaptabilnost umjereno povezana sa zadovoljstvom poslom (Maggiori, Johnston, Krings, Massoudi i Rossier, 2013) i s angažiranošću u radu (Rossier, Zecca, Staufer, Maggiori i Dauwalder, 2012) te da se pojedini statusi profesionalnog identiteta reflektiraju u različitim razinama radne angažiranosti (Luyckx, Duriez, Klimstra i De Witte, 2010). Također se pokazalo da profesionalna zrelost u određenoj mjeri pridonosi boljem postignuću na studiju i na poslu (Crook, Healy i O'Shea, 1984), dok su dvije novije longitudinalne studije pokazale da usporedo s porastom profesionalne zrelosti raste i školski uspjeh (Choi, Kim i Kim, 2015; Oliveira, do Céu Taveira i Porfeli, 2017). U istraživanju provedenom na uzorku hrvatskih srednjoškolaca također je utvrđena niska pozitivna povezanost različitih aspekata profesionalne zrelosti i profesionalnih ishoda (Šverko i Babarović, 2019).

U konačnici, brojna su istraživanja ispitivala povezanost kongruencije i profesionalne zrelosti s profesionalnim ishodima, no opažene korelacije u pravilu su se kretale tek od niskih do umjerenih. To je ukazalo na potrebu da se istraže i druge potencijalne odrednice profesionalnih ishoda. 


\section{Prema širem kontekstu razvoja karijere}

Teorije koje su uslijedile bile su dominantno usmjerene opisivanju procesa razvoja interesa i profesionalnih ciljeva. Zajedničko im je bilo promatranje izbora zanimanja i profesionalnog razvoja u širem kontekstu, kroz naglašavanje utjecaja socijalne okoline pojedinca.

Linda Gottfredson $(1981,2002)$ je u svojoj teoriji ograničavanja i kompromisa uvela rodne stereotipe i percepciju vlastitih intelektualnih i obrazovnih kapaciteta kao preliminarne odrednice razvoja interesa. Po njoj, pojedinac u ranoj dobi postavlja granice na dimenziji maskulinosti-femininosti te na dimenziji prihvatljivoga kognitivnog napora. Postavljanjem tih granica formira se zona prihvatljivih mogućnosti u kojoj su zanimanja odgovarajuće razine maskulinosti, odnosno femininosti, te prihvatljive razine obrazovanja (što je ujedno ekvivalent intelektualnim kapacitetima i prestižu). Tek unutar te zone prihvatljivih mogućnosti pojedinac razvija interese prema nekom od zanimanja. To podrazumijeva da je izbor zanimanja sužen snagom rodnih stereotipa i percepcijom intelektualnih kapaciteta. Stoga se intervencije temeljene u tom pristupu mogu bazirati na proširenju zone prihvatljivih mogućnosti, kako bi pojedinci proširili mogućnosti svoga odabira.

Socijalno kognitivna teorija karijere (Lent, Brown i Hackett, 1994, 2002) stavila je razvoj karijere u širi kontekst. Autori su pretpostavili važan utjecaj niza osobnih i okolinskih obilježja te osobnih iskustava na kognitivne procese koji su u osnovi formiranja interesa, ciljeva i konkretnih koraka u karijeri. Također, istaknuli su važnost pojedinčeve socijalne okoline koja može imati facilitirajući ili inhibirajući utjecaj na postavljanje profesionalnih ciljeva. Oslanjajući se na navedene konstrukte, autori su postavili model razvoja interesa, kontekstualni model izbora karijere te model razvoja profesionalne uspješnosti. Svi modeli naglašavaju važnost samoefikasnosti i očekivanja ishoda te percepcije socijalne podrške ili barijera kao ključnih odrednica razvoja interesa, izbora karijere te razvoja profesionalne uspješnosti. Upravo stoga, u praktičnoj je primjeni ove teorije naglasak na osnaživanju samoefikasnosti te na osvještavanju uloge socijalne okoline u pojedinčevu izbor karijere.

Najnovija teorija konstrukcije karijere (Savickas, 1997, 2002, 2013) usmjerena je na značenje karijere za pojedinca. Značenje karijere izgrađuje se kroz osobne narative u kojima pojedinci izražavaju svoje vrijednosti i pridaju značenja pojedinim događajima u karijeri u kontekstu svoga cjelokupnog života. Ključni je pojam profesionalna adaptabilnost, odnosno sposobnost pojedinca da adekvatno odgovori na zahtjeve vrlo promjenjive i nestabilne radne okoline i svijeta rada današnjice. Teorija je stekla veliku popularnost početkom ovog stoljeća te je postala jedan od dominantnih pristupa razvoju karijere. Niz istraživača podržao je pristup prema kojem je razvoj karijere nemoguće izdvojiti iz cjelovitog životnog razvoja pojedinca. Napisali su manifest o važnosti takvoga holističkog pristupa i time postavili life 
design pristup kao paradigmu profesionalnog usmjeravanja u 21. stoljeću (Savickas i sur., 2009).

Teorija konstrukcije karijere leži na načelima razvojnog pristupa te podrazumijeva promatranje profesionalnog razvoja kroz različite faze. Ovisno o razini izgradnje selfa, pojedinac na različit način poima svoju karijeru te joj pripisuje različita značenja. Tako kao glumac, koji igra uloge u obiteljskom i školskom kontekstu, pojedinac osvještava i izgrađuje svoje interese i vještine. Kao izvršitelj, koji formira svoje profesionalne želje, pojedinac implementira svoje profesionalne izbore donoseći različite profesionalne odluke. Naposljetku kao autor, koji cijelom profesionalnom razvoju daje osobno značenje i interpretaciju, pojedinac formira svoj cjeloviti identitet. Profesionalno savjetovanje u okviru ove teorije temelji se na intervjuu konstrukcije karijere (engl. Career Construction Interview, Savickas, 2014, 2015), u kojem klijent u nekoliko susreta s terapeutom osvještava svoj profesionalni razvoj od najranijih iskustava, razvija osobno značenje karijere i izgrađuje svoj profesionalni identitet.

U okviru teorije Savickas je razvio i sveobuhvatan model konstrukcije karijere kroz prilagodbu, kojim je opisan proces razvoja i izgradnje karijere. Model konstrukcije karijere kroz prilagodbu opisuje razvoj karijere kroz četiri dimenzije: spremnost za prilagodbu, resursi za prilagodbu, ponašanja u smjeru prilagodbe $\mathrm{i}$ ishodi prilagodbe (Savickas, 2002; Savickas i Porfeli, 2012b; Savickas, Porfeli, Lara Hilton i Savickas, 2018). Spremnost za prilagodbu (engl. adaptive readiness) prva je dimenzija modela i predstavlja osnovni preduvjet za konstrukciju karijere. Kako bi uspješno konstruirao svoju karijeru, pojedinac treba imati temeljne osobine koje mu omogućavaju prilagodbu ili profesionalnu tranziciju. To su pojedinčeve osobine i sposobnosti koje facilitiraju razvoj karijere (poput orijentacije prema budućnosti, ekstraverzije, savjesnosti, dobrih intelektualnih kapaciteta). Te osobine facilitiraju razvoj resursa za prilagodbu. Resursi za prilagodbu (engl. adaptability resources) čine drugu dimenziju modela i autori ih definiraju kao profesionalnu adaptabilnost, odnosno sposobnost suočavanja s profesionalnim razvojnim zadacima, tranzicijama ili traumama (Savickas, 1997). Profesionalna adaptabilnost sastoji se od četiri resursa za prilagodbu - usmjerenost na karijeru (engl. concern), kontrola nad vlastitom profesionalnom budućnošću (engl. control), radoznalost ili želja za istraživanjem različitih profesionalnih identiteta $\mathrm{i}$ ishoda (engl. curiosity) te samopouzdanje $\mathrm{u}$ ostvarivanju svojih profesionalnih ciljeva (engl. confidence, Savickas, 2002). Osoba visoke profesionalne adaptabilnosti imat će dobre resurse za razvoj karijere putem prilagodbe jer će biti usmjerena na svoju karijeru, istraživat će različite opcije te će samostalno i samopouzdano donositi profesionalne odluke, odnosno usmjeravati svoju karijeru. Dobri resursi za prilagodbu potiču aktivna ponašanja u smjeru prilagodbe (engl. adapting behaviors), treću točku modela. Taj bihevioralni konstrukt podrazumijeva rad na osvještavanju i ostvarenju svojih profesionalnih ciljeva te se odražava kroz kristalizaciju pojma o sebi, istraživanje različitih profesionalnih opcija, donošenje profesionalnih odluka, razvoj profesionalnih 
vještina, te samu tranziciju u svijet rada. Aktivna i predana ponašanja u smjeru prilagodbe, u konačnici, dovode do pozitivnih ishoda prilagodbe (engl. adaptation results), koji čine posljednju, četvrtu dimenziju modela, a očituju se u profesionalnom zadovoljstvu, stabilnosti i uspješnosti (Savickas i sur., 2018).

Recentne su studije potvrdile valjanost modela konstrukcije karijere kroz prilagodbu. Na temelju empirijskih istraživanja (Hirschi, Hermann i Keller, 2015; Savickas i sur., 2018; Šverko i Babarović, 2019) i metaanaliza (Rudolph, Lavigne i Zacher, 2017; Rudolph, Lavigne, Katz i Zacher, 2017) potvrđeno je kako se bolji profesionalni ishodi ostvaruju uz veću spremnost, snažnije resurse i aktivnija ponašanja u smjeru prilagodbe. Iako je model konstrukcije karijere kroz prilagodbu vrlo širok i uzima u obzir brojne osobne činitelje relevantne za razvoj karijere, on nešto slabije obuhvaća životne okolnosti koje su od velikog značaja za razvoj karijere, poput obiteljskog konteksta, socijalne podrške ili rodnih uloga.

\section{Zaštitni i rizični faktori u razvoju karijere}

Teorije koje obuhvaćaju širi kontekst razvoja karijere (Gottfredson, 1981, 2002; Lent i sur., 1994, 2002; Savickas, 1997, 2002) daju dobar okvir za konceptualizaciju zaštitnih i rizičnih faktora. Oslanjajući se na njih te na osobna profesionalna iskustva i uvide koje smo stekli istraživačkim radom u ovom području, sistematizirali smo zaštitne i rizične faktore koji mogu facilitirati ili inhibirati razvoj karijere. Prema našem poimanju zaštitni i rizični faktori mogu biti osobni, relacijski ili situacijski.

Osobni su faktori psihološke osobine koje mogu imati pozitivan utjecaj na profesionalni razvoj. U literaturi su prepoznati, primjerice, ekstraverzija, savjesnost, orijentacija prema budućnosti, optimizam, fleksibilnost, otpornost na stres, proaktivnost, temeljne samoevaluacije, samoefikasnost, rodno stereotipiziranje, dobri kognitivni kapaciteti pojedinca, školski uspjeh te zdravlje pojedinca. Ekstraverzija i savjesnost umjereno su povezane s radnom angažiranošću i drugim pozitivnim profesionalnim ishodima (Rossier i sur., 2012; Šverko i Babarović, 2019), a njihova je važnost za razvoj karijere potvrđena i u okviru modela konstrukcije karijere kroz prilagodbu (Hirschi i sur., 2015; Rudolph i sur., 2017; Savickas, 2002; Savickas i sur., 2018; Šverko i Babarović, 2019). Nadalje, pozitivna orijentacija prema budućnosti povezana je $s$ profesionalnom zrelošću i $s$ profesionalnim ishodima, posreduje u odnosu profesionalne adaptabilnosti i zadovoljstva životom (Santilli, Marcionetti, Rochat, Rossier i Nota, 2016) te u odnosu profesionalne adaptabilnosti i jasnoće profesionalnih ciljeva (Ginevra, Pallini, Vecchio, Nota i Soresi, 2016). Proaktivnost i temeljne samoevaluacije facilitiraju razvoj karijere, što je potvrđeno u okviru modela konstrukcije karijere kroz prilagodbu (Hirschi i sur., 2015; Šverko i Babarović, 2019), baš kao i samoefikasnost koja potiče profesionalni razvoj u određenom području (Lent i sur., 1994). Sklonost konformiranju rodnim ulogama djeluje na sužavanje profesionalnih izbora (Gottfredson, 1981) te time umanjuje slobodan odabir karijere. Kognitivni 
kapaciteti pojedinca povezani su s obrazovnim i radnim postignućem (Schmidt i Hunter, 1998). Često se odražavaju u školskom uspjehu, koji djeluje na ishode u karijeri (Babarović i Šverko, 2017; Dubow, Huesmann, Boxer, Pulkkinen i Kokko, 2006; Vuolo, Mortimer i Staff, 2014) i profesionalnu zrelost (Babarović, Šverko i Černja, 2016; Negru-Subtirica i Pop, 2016). Lent i suradnici (1994) smatrali su da zdravstveni status i invaliditet djeluju na aktivnosti u koje se pojedinac uključuje (iskustva) te time posredno na cijeli proces razvoja karijere. Također, postojanje zdravstvenih ili psiholoških poteškoća u djetinjstvu pokazalo se ključnim prediktorom opće životne, pa tako i profesionalne dobrobiti u odrasloj dobi (Frijters, Johnston i Shields, 2011).

Relacijski faktori predstavljaju različite socijalne utjecaje koji mogu djelovati pozitivno ili negativno na profesionalni razvoj, počevši od utjecaja roditelja, vršnjaka te društva u cjelini. Važnost socijalne podrške potvrđena je u okviru socijalno kognitivne teorije karijere, a empirijska istraživanja upućuju na to da je njezin efekt na profesionalni izbor izravan, ali i posredan, preko percipirane samoefikasnosti (Lent i sur., 2001; Lent i sur., 2003; Lent, Lopez, Lopez i Sheu, 2008; Lent, Paixão, Da Silva i Leitão, 2010). Roditelji, vršnjaci, prijatelji i opća školska klima mogu biti izvor podrške u upravljanju karijerom, mogu facilitirati orijentaciju prema budućnosti te podići profesionalne aspiracije i profesionalni razvoj (Dietrich i Kracke, 2009; Lindstrom Johnson, Pas i Bradshaw, 2016; Plucker, 1998). Poznata je važnost roditeljskih stilova, koji, prema teoriji samodeterminacije, djeluju na zadovoljenje temeljnih psiholoških potreba i, posljedično, na razvoj autonomnog, intrinzično motiviranog ponašanja (Deci i Ryan, 1985; Ryan i Deci, 2017), što se reflektira na samostalnost i nezavisnost u upravljanju vlastitom karijerom (Guay, 2005; Schröder i Schimtt-Rodermund, 2013; Yu, Zhang, Nunes i Levesque-Bristol, 2018). Naposljetku, način na koji se šira okolina i društvena zajednica odnose prema pojedincu isto tako djeluje na pojedinčev izbor. Diskriminacija na temelju niza osobina priječi pojedince u profesionalnom razvoju i ostvarenju željenih profesionalnih ishoda - od diskriminacije na temelju tjelesnog izgleda (Marlowe, Schneider i Nelson, 1996), na temelju invaliditeta (Szymanski i Hanley-Maxwell, 1996), dobi (Wood, Wilkinson i Harcourt, 2008), roda (Phillips i Imhoff, 1997), pa do diskriminacije na temelju etničke (Fouad i Byars-Winston, 2005) i vjerske pripadnosti (Duffy, 2006).

Situacijski faktori predstavljaju različite vanjske utjecaje koji mogu djelovati na razvoj karijere. Od životnih okolnosti značajan utjecaj na profesionalni razvoj i profesionalne ishode mogu imati socioekonomski status te prilike u mjestu stanovanja pojedinca. Brojna su istraživanja potvrdila nepovoljan utjecaj niskoga socioekonomskog statusa obitelji na profesionalne ishode (npr. Armstrong i Crombie, 2000; Fouad i Brown, 2000; Trusty, 1998; Turner i Lapan, 2003). Nizak socioekonomski status obitelji često je povezan sa slabom obiteljskom podrškom za razvoj i usmjeravanje karijere, koja inače ima facilitirajući utjecaj na profesionalni razvoj (Keller i Whiston, 2008; Thompson i Subich, 2006). Bilo da se radi o niskim 
materijalnim primanjima ili o niskom obrazovanju roditelja, djeca niskoga socioekonomskog statusa imaju manje obrazovnih prilika i imaju sužen izbor mogućih puteva u karijeri. Prilike u mjestu stanovanja također mogu ograničavati ne samo profesionalne izbore nego i mogućnosti za izgradnju i razvoj karijere.

Pojedinci izloženi nepoželjnom djelovanju osobnih, socijalnih i okolinskih faktora imaju smanjene mogućnosti za razvoj karijere. Posebnu opasnost predstavlja njihovo združeno djelovanje, odnosno njihov zajednički učinak na pojedinca jer izloženost većem broju rizičnih faktora pojačava njihove negativne efekte na profesionalni razvoj (Babarović i sur., 2016).

\section{Učinci praktičnih intervencija profesionalnog usmjeravanja}

Pojedinci izloženi rizičnim faktorima imaju nepovoljne uvjete za profesionalni razvoj i za postizanje dobrih profesionalnih ishoda. Oni najčešće svoje zanimanje i karijeru biraju tek unutar vrlo ograničenog spektra zanimanja i postižu nepovoljnije profesionalne ishode (Babarović i sur., 2016). Istovremeno, takvi su pojedinci vrlo često manje motivirani za usmjeravanje svoje karijere, pa ne traže pomoć stručnjaka niti participiraju u ponuđenim programima. Upravo zato bi za dobrobit svakog pojedinca i za razvoj pravednijeg društva u cjelini, bilo nužno razvijati i organizirati intervencije i programe za profesionalno usmjeravanje koji bi zahvaćali i pojedince izložene rizičnim faktorima. Naravno, školsko je okruženje vrlo prikladno za to, zato što se u školi pomoć i podrška u razvoju karijere mogu pružiti svima, i to bez dodatne naknade.

Intervencije za pomoć pri usmjeravanju i konstrukciji karijere najčešće su utemeljene u diferencijalističkom ili razvojnom pristupu. Diferencijalistički pristup podrazumijeva pružanje jednokratne pomoći u vidu savjeta o prikladnom zanimanju ili obrazovnom programu, dok razvojni pristup uključuje dugoročniji rad s korisnicima na osnaživanju njihovih temeljnih osobina važnih za samostalno usmjeravanje karijere. Ovi se pristupi nadopunjuju, pa je u nekim situacijama važno dati dobar jednokratan savjet o izboru karijere, dok je, s druge strane, isto tako važno kontinuirano raditi s učenicima i time poticati njihov profesionalni razvoj.

Radionice organizirane tijekom dužega vremenskog razdoblja mogu omogućiti učenicima da pravovremeno prepoznaju važnost prikladnog odabira zanimanja te da podignu razinu profesionalne zrelosti i informiranosti o svijetu rada. Śkolski programi profesionalnog razvoja efikasni su u poticanju profesionalnog razvoja i profesionalne zrelosti učenika. Metaanalize različitih programa i intervencija (Oliver i Spokane, 1988; Whiston, Sexton i Lasoff, 1998), kao i empirijske studije provedene na hrvatskim uzorcima (Babarović, Blažev, Dević i Šverko, 2017), potvrdile su njihove umjereno pozitivne učinke na podizanje različitih aspekata profesionalne zrelosti mladih.

Danas postoji i niz besplatnih online-alata za profesionalno usmjeravanje. Takvi su se računalni sustavi počeli razvijati i koristiti već 60 -ih godina prošlog stoljeća te 
su danas općeprihvaćeni alati u sustavu karijernog savjetovanja (Harris-Bowlsbey, 2013). Dosadašnja su istraživanja pokazala da korištenje računalnih sustava ima niz pozitivnih učinaka na različite elemente profesionalnog razvoja. Njihova primjena djeluje na povećanje sigurnosti u profesionalnu odluku, smanjuje karijernu neodlučnost, odnosno podiže razinu doživljene samoefikasnosti prilikom odlučivanja (Betz i Borgen, 2009; Eveland, Conyne i Blakney, 1998; Fukuyama, Probert, Neimeyer, Nevill i Metzler, 1988). Također, pozitivni učinci računalnih sustava vidljivi su u boljem razvoju profesionalnog identiteta (Mau, 1999), višoj razini profesionalne zrelosti (Luzzo i Pierce, 1996) te u većem zadovoljstvu odabranom karijerom (Gati, Gadassi i Shemesh, 2006). Ipak, metaanaliza kojom su uspoređivani različiti modaliteti intervencija u području profesionalnog savjetovanja pokazala je da korištenje računalnih sustava dopunjeno i podržano savjetovanjem „lice u lice“ rezultira znatno boljim rezultatima u usporedbi sa samostalnom uporabom računala (Whiston, Brecheisen i Stephens, 2003). Također se pokazalo da strukturirane radionice i grupni programi profesionalnog razvoja u kombinaciji s računalno potpomognutim savjetovanjem imaju dobar učinak (Oliver i Spokane, 1988).

U Hrvatskoj postoji niz besplatnih alata za profesionalno usmjeravanje mladih: Školski program profesionalnog razvoja za osnovne i srednje škole (Perry i VanZandt, 1999a, 1999b) te stranice za profesionalno usmjeravanje Put karijere Eusmjeravanje, Vodič kroz zanimanja i Karijera.hr (linkovi i detaljniji prikaz u Dodatku). Svi su navedeni alati besplatni i javno dostupni te su prošli sustavne validacije koje su pokazale opravdanost njihova korištenja. Njihova dostupnost i samoprimjenjivost omogućava pružanje profesionalnog usmjeravanje za sve, bez obzira na socioekonomski status korisnika ili njegovu geografsku izoliranost. Kada bi se ovakvi programi i alati primjenjivali u školi, idealno u okviru redovnog kurikuluma, u kombinaciji $\mathrm{s}$ grupnim ili, prema potrebi, individualnim savjetovanjem, sva bi djeca imala priliku dobiti adekvatnu pomoć i podršku u svom profesionalnom razvoju.

Profesionalno usmjeravanje može ublažiti neželjeno djelovanje rizičnih faktora jer se njime mogu zahvatiti i učenici izloženi riziku, koji su često manje motivirani za razvoj karijere, ne traže pomoć stručnjaka niti participiraju u programima. Upravo je zato važno potaknuti primjenu različitih alata za profesionalno usmjeravanje u školama, jer školsko okruženje pruža mogućnost da se pomoć i podrška pruže svima, što je ključno za dobrobit svakog pojedinca, ali i za razvoj pravednijeg društva u cjelini.

\section{Zaključak}

Teorijski modeli razvoja karijere uključuju, u većoj ili manjoj mjeri, potencijalne osobne i okolinske utjecaje, no ne razlažu sistematično zaštitne i rizične 
faktore koji mogu facilitirati ili inhibirati profesionalni razvoj i razvoj karijere. Pregledom literature i vlastitim istraživanjima došli smo spoznaja o pojedinačnim zaštitnim i rizičnim faktorima koji djeluju na razvoj karijere. U ovom smo radu sistematizirali zaštitne i rizične faktore u razvoju karijere u tri kategorije: osobne faktore (psihološke osobine pojedinca), relacijske faktore (socijalne utjecaje) te situacijske faktore (utjecaje životnog okruženja). Efekti pojedinačnih konstrukata koji ulaze u svaku od kategorija na profesionalni razvoj dobro su dokumentirani u literaturi, no sistematična konceptualizacija zaštitnih i rizičnih faktora dosad nije postojala. Ovakva sistematizacija omogućava istraživačima i praktičarima da vode računa o nizu zaštitnih i rizičnih faktora koji za neke pojedince mogu imati pozitivan, a za neke negativan učinak. Ovime se istraživačima daje uvid u konstrukte čiji je utjecaj potrebno istraživati ili kontrolirati u istraživanjima, dok praktičarima može služiti kao indikator potencijalnih rizika te ih upozoriti na adolescente kojima je potrebna posebna pomoć i podrška u razvoju karijere. Procesom profesionalnog usmjeravanja ključno je obuhvatiti pojedince izložene nepovoljnom utjecaju rizičnih faktora, te je stoga važno profesionalno usmjeravanje provoditi sustavno i temeljito, za što je idealno školsko okruženje. U Hrvatskoj imamo niz besplatnih i dostupnih alata za profesionalno usmjeravanje (prikazani u Dodatku), koji čine dobar temelj za provođenje profesionalnog usmjeravanja u školama.

\section{Literatura}

Armstrong, P. I. i Crombie, G. (2000). Compromises in adolescents' occupational aspirations and expectations from grades 8 to 10. Journal of Vocational Behavior, 56(1), 82-98.

Babarović, T. i Šverko, I. (2011). Profesionalna zrelost učenika viših razreda osnovnih škola. Suvremena psihologija, 14(1), 91-109.

Babarović, T. i Šverko, I. (2016). Vocational development in adolescence: Career construction, career decision-making difficulties and career adaptability of Croatian high-school students. Primenjena psihologija, 9(4), 429-448.

Babarović, T. i Šverko, I. (2019). The validity of Career Decision-Making Difficulties Questionnaire in Croatia. Journal of Career Assessment, 27(3), 391-407. https://doi.org/ $10.1177 / 1069072717748960$

Babarović, T. i Šverko, I. (2107, listopad). The career transition outcomes of disadvantaged groups of adolescents. Izlaganje na konferenciji Decent work, equity and inclusion: Passwords, for the present and the future, Padova, Italija.

Babarović, T., Blažev, M., Dević, I. i Šverko, I. (2107, studeni). The effectiveness of shortterm career development program in middle schools. Izlaganje na konferenciji Career guidance in a changing world, Prag, Češka. 
Babarović, T., Šverko, I. i Černja, I. (2016, lipanj). Career choices and vocational development of disadvantaged groups of adolescents. Izlaganje na konferenciji Interventions for career-and-life design for sustainable development and decent work, Wroclaw, Poljska.

Babarović, T., Šverko, I. i Crnko, I. (2017). Work values of Croatian adolescents: Value hierarchy and importance of family background. U: V. Hedrih (Ur.), Work and family relations at the beginning of the 21st century - international thematic proceedings book (str. 59-72). Faculty of Philosophy, University of Niš: Niš, Serbia.

Babarović, T., Tokalić, R. i Šverko, I. (2018, listopad). Career decision-making profiles of Croatian high school students: The structure of profiles and relation to other careerrelated constructs. Izlaganje na konferenciji Conference of the International Association of Educational and Vocational Guidance (IAEVG), Göteborg, Švedska.

Betz, N. E. i Borgen, F. H. (2009). Comparative effectiveness of CAPA and Focus on-line career assessment systems with undecided college students. Journal of Career Assessment, 17, 351-366. doi:10.1177/ 1069072709334229

Choi, Y., Kim, J. i Kim, S. (2015). Career development and school success in adolescents: The role of career interventions. Career Development Quarterly, 63(2), 171-186.

Crook, R. H., Healy, C. C. i O'Shea, D. W. (1984). The linkage of work achievement to selfesteem, career maturity, and college achievement. Journal of Vocational Behavior, 25(1), 70-79. http://dx.doi.org/10.1016/0001-8791(84)90037-X

Dawis, R. V. i Lofquist, L. H. (1984). A psychological theory of work adjustment. Minneapolis: University of Minnesota Press.

Deci, E. L. i Ryan, R. M. (1985). Intrinsic motivation and self-determination in human behavior. New York: Plenum.

Dietrich, J. i Kracke, B. (2009). Career-specific parental behaviors in adolescents' development. Journal of Vocational Behavior, 75(2), 109-119.

Dubow, E. F., Huesmann, L. R., Boxer, P., Pulkkinen, L. i Kokko, K. (2006). Middle childhood and adolescent contextual and personal predictors of adult educational and occupational outcomes: A mediational model in two countries. Developmental Psychology, 42(5), 937-949.

Duffy, R. D. (2006). Spirituality, religion, and career development: Current status and future directions. The Career Development Quarterly, 55(1), 52-63.

Eveland, A. P., Conyne, R. K. i Blakney, V. L. (1998). University students and career decidedness: Effects of two computer-based career guidance interventions. Computers in Human Behavior, 14, 531-541.

Fouad, N. A. i Brown, M. T. (2000). Role of race and social class in development: Implications for counseling psychology. U: S. D. Brown i R. W. Lent (Ur.), Handbook of counseling psychology (str. 379-408). Hoboken, NJ: John Wiley. 
Fouad, N. A. i Byars-Winston, A. M. (2005). Cultural context of career choice: Metaanalysis of race/ethnicity differences. The Career Development Quarterly, 53(3), 223233.

Frijters, P., Johnston, D. W. i Shields, M. A. (2011). Destined for (un)happiness: Does childhood predict adult life satisfaction? IZA Discussion Paper No. 5819.

Fukuyama, M. A., Probert, B. S., Neimeyer, G. J., Nevill, D. D. i Metzler, A. E. (1988). Effects of DISCOVER on career self-efficacy and decision making of undergraduates. Career Development Quarterly, 37, 56-62.

Gati, I. (1998). Using career-related aspects to elicit preferences and characterize occupations for a better person-environment fit. Journal of Vocational Behavior, 52, 343-356.

Gati, I., Gadassi, R. i Mashiah-Cohen, R. (2012). Career decision-making profiles vs. styles: Convergent and incremental validity. Journal of Vocational Behavior, 81(1), 2-16.

Gati, I., Gadassi, R. i Shemesh, N. (2006). The predictive validity of a computer-assisted career decision-making system: A six-year follow-up. Journal of Vocational Behavior, 68(2), 205-219.

Gati, I., Garty, Y. i Fassa, N. (1996). Using career-related aspects to assess personenvironment fit. Journal of Counseling Psychology, 43, 196-206.

Gati, I., Krausz, M. i Osipow, S. H. (1996). A taxonomy of difficulties in career decisionmaking. Journal of Counseling Psychology, 43, 510-526.

Ginevra, M. C., Pallini, S., Vecchio, G. M., Nota, L. i Soresi, S. (2016). Future orientation and attitudes mediate career adaptability and decidedness. Journal of Vocational Behavior, 95, 102-110.

Gottfredson, L. S. (1981). Circumscription and compromise: A developmental theory of occupational aspirations. Journal of Counseling Psychology Monograph, 28(6), 545579.

Gottfredson, L. S. (2002). Gottfredson's theory of circumscription, compromise, and selfcreation. U: D. Brown (Ur.), Career Choice and Development $\left(4^{\text {th }}\right.$ ed, 85-148). San Francisco: Jossey-Bass.

Guay, F. (2005). Motivations underlying career decision-making activities: The Career Decision-Making Autonomy Scale (CDMAS). Journal of Career Assessment, 13(1), 77-97. doi:10.1177/10690727042702972

Harris-Bowlsbey, J. (2013). Computer-assisted guidance systems: A part of NCDA history. The Career Development Journal, 81, 181-186.

Hirschi, A., Herrmann, A. i Keller, A. C. (2015). Career adaptivity, adaptability, and adapting: A conceptual and empirical investigation. Journal of Vocational Behavior, 87(87), 110. https://doi.org/10.1016/j.jvb.2014.11.008

Holland, J. L. (1959). A theory of vocational choice. Journal of Counseling Psychology, 6, $35-45$. 
Holland, J. L. (1997). Making vocational choices: A theory of vocational personalities and work environments (3rd ed.). Odessa, FL: Psychological Assessment Resources.

Keller, B. K. i Whiston, S. C. (2008). The role of parental influences on young adolescents' career development. Journal of Career Assessment, 16(2), 198-217.

Lent, R. W., Brown, S. D. i Hackett, G. (1994). Toward a unifying social cognitive theory of career and academic interest, choice, and performance. Journal of Vocational Behavior, 45(1), 79-122. https://doi.org/10.1006/jvbe.1994.1027

Lent, R. W., Brown, S. D. i Hackett, G. (2002). Social cognitive career theory. U: D. Brown (Ur.), Career choice and development (str. 255-311). San Francisco: Jossey-Bass.

Lent, R. W., Brown, S. D., Brenner, B., Chopra, S. B., Davis, T., Talleyrand, R. i Suthakaran, V. (2001). The role of contextual supports and barriers in the choice of math/science educational options: A test of social cognitive hypotheses. Journal of Counseling Psychology, 48(4), 474-483.

Lent, R. W., Brown, S. D., Schmidt, J., Brenner, B., Lyons, H. i Treistman, D. (2003). Relation of contextual supports and barriers to choice behavior in engineering majors: Test of alternative social cognitive models. Journal of Counseling Psychology, 50(4), 458-464.

Lent, R. W., Lopez, A. M., Lopez, F. G. i Sheu, H. B. (2008). Social cognitive career theory and the prediction of interests and choice goals in the computing disciplines. Journal of Vocational Behavior, 73(1), 52-62.

Lent, R. W., Paixão, M. P., Da Silva, J. T. i Leitão, L. M. (2010). Predicting occupational interests and choice aspirations in Portuguese high school students: A test of social cognitive career theory. Journal of Vocational Behavior, 76(2), 244-251.

Lindstrom Johnson, S., Pas, E. i Bradshaw, C. P. (2016). Understanding the association between school climate and future orientation. Journal of Youth and Adolescence, 45(8), 1575-1586. https://doi.org/10.1007/s10964-015-0321-1

Luyckx, K., Duriez, B., Klimstra, T. i De Witte, H. (2010). Identity statuses in young adult employees. Journal of Vocational Behavior, 77(3), 339-349.

Luzzo, D. A. i Pierce, G. (1996). Effects of DISCOVER on the career maturity of middle school students. The Career Development Quarterly, 45(2), 170-172. doi:10.1002/j.2161-0045.1996.tb00267.x

Maggiori, C., Johnston, C., Krings, F., Massoudi, K. i Rossier, J. (2013). The role of career adaptability and work conditions on general and professional well-being. Journal of Vocational Behavior, 83, 437-449.

Marlowe, C. M., Schneider, S. L. i Nelson, C. E. (1996). Gender and attractiveness biases in hiring decisions: Are more experienced managers less biased? Journal of Applied Psychology, 81(1), 11-21.

Mau, W. (1999). Effects of computer-assisted career decision making on vocational identity and career exploratory behaviors. Journal of Career Development, 25, 261-274. 
Negru-Subtirica, O. i Pop, E. I. (2016). Longitudinal links between career adaptability and academic achievement in adolescence. Journal of Vocational Behavior, 93, 163-170.

Nye, C. D., Prasad, J., Bradburn, J. i Elizondo, F. (2018). Improving the operationalization of interest congruence using polynomial regression. Journal of Vocational Behavior, 104, 154-169.

Oliveira, Í. M., do Céu Taveira, M. i Porfeli, E. J. (2017). Career preparedness and school achievement of Portuguese children: Longitudinal trend articulations. Frontiers in Psychology, 8, Article 618.

Oliver, L. W. i Spokane, A. R. (1988). Career-intervention outcome: What contributes to client gain? Journal of Counseling Psychology, 35, 447-462.

Perry, N. i VanZandt, Z. (1999a). Razmisli o budućnosti: Školski program profesionalnog razvoja za osnovne škole. Zagreb: Društvo za istraživanje i razvoj ljudskih potencijala Razbor.

Perry, N. i VanZandt, Z. (1999b). Usredotoči se na budućnost: Školski program profesionalnog razvoja za srednje škole. Zagreb: Društvo za istraživanje i razvoj ljudskih potencijala Razbor.

Perry, N. i VanZandt, Z. (2006a). Exploring future options: A career development curriculum for middle school students. G-Reference, Information and Interdisciplinary Subjects Series. USA: IDEA.

Perry, N. i VanZandt, Z. (2006b). Focus on the future: A career development curriculum for secondary school students. G-Reference, Information and Interdisciplinary Subjects Series. USA: IDEA.

Phillips, S. D. i Imhoff, A. R. (1997). Women and career development: A decade of research. Annual Review of Psychology, 48(1), 31-59.

Plucker, J. A. (1998). The relationship between school climate conditions and student aspirations. The Journal of Educational Research, 91(4), 240-246.

Porfeli, E. J., Lee, B., Vondracek, F. W. i Weigold, I. (2011). A multi-dimensional measure of vocational identity status. Journal of Adolescence, 34(5), 853-871.

Rossier, J., Zecca, G., Staufer, S. D., Maggiori, C. i Dauwalder, J. P. (2012). Career AdaptAbilities Scale in a French-speaking Swiss sample: Psychometric properties and relationships to personality and work engagement. Journal of Vocational Behavior, 80, 734-743.

Rounds, J. i Su, R. (2014). The nature and power of interests. Current Directions in Psychological Science, 23(2), 98-103.

Rudolph, C. W., Lavigne, K. N. i Zacher, H. (2017). Career adaptablility: A meta-analysis of relationships with measures of adaptivity, adapting responses, and adaptation results. Journal of Vocational Behavior, 98, 17-34. https://doi.org/10.1016/j.jvb.2016.09.002

Rudolph, C. W., Lavigne, K. N., Katz, I. M. i Zacher, H. (2017). Linking dimensions of career adaptability to adaptation results: A meta-analysis. Journal of Vocational Behavior, 102, 151-173. https://doi.org/10.1016/j.jvb.2017.06.003 
Ryan, R. M. i Deci, E. L. (2017). Self-determination theory: Basic psychological needs in motivation, development and wellness. New York, NY: Guilford Publications.

Santilli, S., Marcionetti, J., Rochat, S., Rossier, J. i Nota, L. (2017). Career adaptability, hope, optimism, and life satisfaction in Italian and Swiss adolescents. Journal of Career Development, 44(1), 62-76.

Savickas, M. L. (1997). Career adaptability: An integrative construct for life-span, life space theory. The Career Development Quarterly, 45, 247-259. doi:10.1002/j.2161-0045. 1997.tb00469.x

Savickas, M. L. (2002). Career construction: A developmental theory of vocational behaviour. U: D. Brown (Ur.), Career choice and development ( $4^{\text {th }}$ ed, str. 149-205). San Francisco: Jossey-Bass.

Savickas, M. L. (2013). Career construction theory and practice. U: S. D. Brown i R. W Lent (Ur.), Career development and counseling handbook: Putting theory and research to work ( $2^{\text {nd }}$ ed, str. 147-183). Hokoben, NJ: John Wiley \& Sons.

Savickas, M. L. (2014). Work values: A career construction elaboration. U: M. Pope, L. Y. Flores i P. J. Rottinghaus (Ur.), The role of values in careers (str. 87-99). Charlotte, NC: IAP Information Age Publishing.

Savickas, M. L. (2015). Life-design counseling manual. Lexington KY, USA.

Savickas, M. L., Nota, L., Rossier, J., Dauwalder, J. P., Duarte, M. E., Guichard, J., ... van Vianen, A. E. M. (2009). Life designing: A paradigm for career construction in the $21 \mathrm{st}$ century. Journal of Vocational Behaviour, 75, 239-250.

Savickas, M. L. i Porfeli, E. J. (2012a). Career Adapt-Abilities Scale. Rootstown, OH: Vocopher.com.

Savickas, M. L. i Porfeli, E. J. (2012b). Career Adapt-Abilities Scale: Construction, reliability, and measurement equivalence across 13 countries. Journal of Vocational Behavior, 80, 661-673. doi:10.1016/j.jvb.2012.01.011

Savickas, M. L., Porfeli, E. J., Lara Hilton, T. i Savickas, S. (2018). The Student Career Construction Inventory. Journal of Vocational Behavior, 106, 138-152. doi:10.1016/j. jvb.2018.01.009

Schmidt, F. L. i Hunter, J. E. (1998). The validity and utility of selection methods in personnel psychology. Psychological Bulletin, 124(2), 262-274. doi:10.1037/0033-2909.124. 2.262

Schröder, E. i Schmitt-Rodermund, E. (2013). Antecedents and consequences of adolescents' motivations to join the family business. Journal of Vocational Behavior, 83, 476-485.

Spokane, A. R., Meir, E. I. i Catalano, M. (2000). Person-environment congruence and Holland's theory. Journal of Vocational Behavior, 57, 137-187.

Stoll, G., Rieger, S., Lüdtke, O., Nagengast, B., Trautwein, U. i Roberts, B. W. (2017). Vocational interests assessed at the end of high school predict life outcomes assessed 10 years later over and above IQ and Big Five personality traits. Journal of Personality and Social Psychology, 113(1), 167-184. 
Su, R., Tay, L., Liao, H. Y., Zhang, Q. i Rounds, J. (2019). Toward a dimensional model of vocational interests. Journal of Applied Psychology, 104(5), 690-714.

Super, D. E. (1953). A theory of vocational development. American Psychologist, 8, 185-190.

Super, D. E. (1957). The psychology of careers. New York: Harper \& Row.

Super, D. E. (1994). A life-span, life-space perspective on convergence. U: M. L. Savickas i R. W. Lent (Ur.), Convergence in career development theories (str. 63-71). Palo Alto, CA: Consulting Psychologists Press.

Šverko, I. (2008). Spherical model of interests in Croatia. Journal of Vocational Behavior, $72,14-24$.

Šverko, I. i Babarović, T. (2016). Integrating personality and career adaptability into vocational interest space. Journal of Vocational Behavior, 94, 89-103.

Šverko, I. i Babarović, T. (2018, listopad). Vocational identity of high school students: The role of vocational identity status in career development of adolescents. Izlaganje na konferenciji Conference of the International Association of Educational and Vocational Guidance (IAEVG), Göteborg, Švedska.

Šverko, I. i Babarović, T. (2019). Applying Career construction model of adaptation to career transition in adolescence: A two-study paper. Journal of Vocational Behavior, 111, 5973. https://doi.org/10.1016/j.jvb.2018.10.011

Šverko, I., Babarović, T. i Kos, S. (2017). Nomological Network of RIASEC Types: Interests, Personality Traits, Work Values and Life Role Salience. U: V. Hedrih (Ur.), Work and family relations at the beggining of the 21 st century - international thematic proceedings book (str. 21-36). Niš, Srbija: Faculty of Philosophy, University of Niš.

Šverko, I., Babarović, T. i Međugorac, V. (2014). Pictorial assessment of interests: Development and evaluation of Pictorial and Descriptive Interest Inventory. Journal of Vocational Behavior, 84, 356-366.

Šverko, B., Akik, N., Babarović, T., Brčina, A. i Šverko, I. (2002) Validity of e-advice: The evaluation of an internet-based system for career planning. International Journal for Educational and Vocational Guidance, 2(3), 193-215.

Szymanski, E. M. i Maxwell, C. H. (1996). Career development of people with developmental disabilities: An ecological model. Journal of Rehabilitation, 62(1), 48-55.

Taylor, K. M. i Betz, N. E. (1983). Applications of self-efficacy theory to the understanding and treatment of career indecision. Journal of Vocational Behavior, 22(1), 63-81.

Thompson, M. N. i Subich, L. M. (2006). The relation of social status to the career decisionmaking process. Journal of Vocational Behavior, 69(2), 289-301.

Tinsley, H. E. A. (2000). The congruence myth: An analysis of the efficacy of the personenvironment fit model. Journal of Vocational Behavior, 56, 147-179.

Tranberg, M., Slane, S. i Ekerberg, S. E. (1993). The relationship between interest congruence and satisfaction: A meta-analysis. Journal of Vocational Behavior, 42, 253-264. 
Trusty, J. (1998). Family influences on educational expectations of late adolescents. The Journal of Educational Research, 91(5), 260-271.

Tsabari, O., Tziner, A. i Meir, E. I. (2005). Updated meta-analysis on the relationship between congruence and satisfaction. Journal of Career Assessment, 13(2), 216-232.

Turner, S. L. i Lapan, R. T. (2003). The measurement of career interests among at-risk innercity and middle-class suburban adolescents. Journal of Career Assessment, 11(4), 405420.

Van Iddekinge, C. H., Roth, P. L., Putka, D. J. i Lanivich, S. E. (2011). Are you interested? A meta-analysis of relations between vocational interests and employee performance and turnover. Journal of Applied Psychology, 96, 1167-1194.

Vuolo, M., Mortimer, J. T. i Staff, J. (2014). Adolescent precursors of pathways from school to work. Journal of Research on Adolescence, 24(1), 145-162.

Whiston, S. C., Sexton, T. L. i Lasoff, D. L. (1998). Career-intervention outcome: A replication and extension of Oliver and Spokane (1988). Journal of Counseling Psychology, 45(2), 150-165. http://dx.doi.org/10.1037/0022-0167.45.2.150

Whiston, S. C., Brecheisen, B. K. i Stephens, J. (2003). Does treatment modality aff ect career counseling eff ectiveness? Journal of Vocational Behavior, 62, 390-410.

Wilkins, K. G. i Tracey, T. J. (2014). Person environment fit and vocational outcomes. U: M. Coetzee (Ur.), Psycho-social career meta-capacities (str. 123-138). Cham: Springer.

Wille, B., Tracey, T. J. G., Feys, M. i De Fryut, F. (2014). A longitudinal and multi-method examination of interest-occupation congruence within and across time. Journal of Vocational Behavior, 84, 59-73.

Wood, G., Wilkinson, A. i Harcourt, M. (2008). Age discrimination and working life: Perspectives and contestations - a review of the contemporary literature. International Journal of Management Reviews, 10(4), 425-442.

Yu, S., Zhang, F., Nunes, L. D. i Levesque-Bristol, C. (2018). Self-determined motivation to choose college majors, its antecedents, and outcomes: A cross-cultural investigation. Journal of Vocational Behavior, 108, 132-150. 


\title{
Protective and Risk Factors in Career Development and Possible Interventions in the School Context
}

\begin{abstract}
This paper gives a review and new systematization of protective and risk factors that influence an individual's career development. According to the proposed conceptualization, protective and risk factors in career arise from personal, relational, and situational domains. Personal factors are psychological traits that have been evidenced in the literature to influence career development, such as extraversion, conscientiousness, future orientation, optimism, flexibility, stress resilience, selfefficacy, cognitive capacity, or the health of an individual. Relational factors include social influences that can have either positive or negative effect on career development, starting with the influence of parents, peers, and society, and manifest through social support and different relational styles. Situational factors represent different external influences that can influence career development, of which the socio-economic status and opportunities in the individual's place of residence are clearly recognized in the literature. The paper elaborates on the effects that protective and risk factors have on career development. Also, the paper points to available tools for career counselling of adolescents that can mitigate the undesirable effects of risk factors.
\end{abstract}

Keywords: career development, protective and risk factors, career counselling, adolescence

Primljeno: 30.09.2019. 


\section{Dodatak}

\section{Alati za profesionalno usmjeravanje}

Put karijere

www.putkarijere.hr
- razvijen 2017. godine u okviru istraživačkog projekta Hrvatske zaklade za znanost Profesionalni razvoj u adolescenciji: određenje modela tranzicije karijere;

- sadrži mjere profesionalnih interesa (slikovno-opisni upitnik interesa i upitnik interesa PGI), radnih vrijednosti (V-upitnik), profesionalne adaptabilnosti (Skala profesionalne adaptabilnosti), profesionalne zrelosti (Skala spremnosti za karijeru i Test informiranosti o zanimanjima), profesionalnog identiteta (Skala statusa profesionalnog identiteta) te mjere poteškoća i stilova odlučivanja o karijeri (Upitnik poteškoća u donošenju profesionalnih odluka i Profil donošenja profesionalnih odluka);

- daje povratne informacije korisnicima o ispitivanim osobinama i sugerira korake koji mogu podići razinu profesionalne zrelosti i informiranosti;

- empirijski čvrsto potvrđena valjanosti svih mjera (npr. Babarović i Šverko, 2011; Babarović i Šverko, 2016; Babarović i Šverko, 2019; Babarović, Šverko i Crnko, 2017; Babarović, Tokalić i Šverko, 2018; Šverko, 2008; Šverko i Babarović, 2016; Šverko i Babarović, 2018; Šverko, Babarović i Kos, 2017; Šverko, Babarović i Međugorac, 2014)

- razvijen 2015. godine u okviru europskih pretpristupnih fondova (IPA);

E-usmjeravanje

- sadrži opsežne informacijama o svijetu rada, obrazovnim programima i mogućnostima stipendiranja, apliciranja za

http://epotpore te zapošljavanju;

usmjeravanje.hzz.hr

- uključuje online-upitnik za profesionalno usmjeravanje Moj izbor, koji na temelju samoprocjene preferencija i kompetencija za pojedine aspekte posla klijentu daje informaciju o prikladnim zanimanjima

- razvijen tijekom 2000-ih;

- sadrži nekoliko samoprimjenjivih upitnika za razvoj

Karijera.hr karijere i izbor zanimanja koji su svi prošli sustavne provjere (npr. Babarović i Šverko, 2011; Babarović i

www.karijera.hr Šverko, 2019; Šverko i sur., 2014);

- svi upitnici daju povratnu informaciju o pojedinčevim interesima, profesionalnoj zrelosti ili poteškoćama u donošenju profesionalnih odluka 
Šverko, I., Babarović, T.:

- prvi je online-alat za profesionalno usmjeravanje učenika u Hrvatskoj, razvijen 1999. godine;

- sadrži upute za planiranje karijere i opise 260 najčešćih

Vodič kroz zanimanja zanimanja u Hrvatskoj te upitnik profesionalnih sklonosti na temelju kojeg se pojedincu daje profesionalni savjet o

http://mrav.ffzg.hr/zanima nja prikladnim zanimanjima;

- valjanost tog sustava za profesionalno usmjeravanje čvrsto je potvrđena empirijski (Šverko, Babarović, Akik, Brčina i Šverko, 2002)

- napomena: Baza zanimanja relativno je zastarjela i treba je osuvremeniti novim informacijama i zanimanjima

- sustav od 36 vježbi za primjenu u osnovnoj i srednjoj školi kojemu je cilj osnaživanje učenika u procesu izbora

Školski program zanimanja;

profesionalnog razvoja

- inačica za osnovne i srednje škole Razmisli o budućnosti i Usredotoči se na budućnost (Perry i VanZandt, 1999a,

http://www.putkarijere.hr/ 1999b, 2006a, 2006b) sadrže detaljno opisane pripreme

strucne-informacijel za radionice, primjenjive u nastavi;

skolski-program-

profesionalnog-razvoja

- cjelovite je knjižice moguće besplatno skinuti sa stranica Karijera.hr i Put karijere

- eksperimentalnim je istraživanjem potvrđena efikasnost primjene ovog programa (Babarović i sur., 2017) 